\title{
ASsessment of Nurses Knowledge About Preventive and Therapeutic Measures of Postpartum Hemorrhage
}

\author{
Loura K. Abd-Elgany ${ }^{1}$, Kamal M. Zahran ${ }^{2}$, \& Nadia H. Ahmed ${ }^{3}$ \& Hamida A. Abd-Elhafez ${ }^{4}$ \\ 1. Nursing Specialist in El-Mabara Hosbital ${ }^{1}$ \\ 2. Professor of Obstetrics and Gynecology-Faculty of Medicine - Assiut University ${ }^{2}$ \\ 3. Assistant Professor of Obstetrics and Gynecological Nursing -Faculty of Nursing - Assiut University ${ }^{3}$ \\ 4. Assistant Professor of Obstetrics and Gynecological Nursing -Faculty of Nursing - Assiut University ${ }^{4}$
}

\begin{abstract}
Background: Postpartum hemorrhage remains one of the major causes of maternal death that occurs worldwide which can be preventable and treatable. Aims of the Study: Assess of maternity nurses knowledge about preventive and therapeutic measures of postpartum hemorrhage. The effect of teaching program about preventive and therapeutic measures of postpartum hemorrhage on improving maternity nurses knowledge through implementation development. Setting: In woman's health university and El-Mabara hospital at Assiut city. Design: A quasi experimental (pre/post - test) has been used in this study. Sample: A convenient sample (62) has been used (25) of them from woman health hospital, (37) of them from El-Mabara hospital. Tools: Two tools were used (1) selfadministrative questionnaire has been used to collect data. (2) Teaching program with booklet. Results: The findings reported that more than half of them aged 30 years or more and had secondary education, Most of them had unsatisfactory knowledge about the prevention of postpartum hemorrhage. But, unsatisfactory this knowledge has been improved after program implemented. Conclusion: Nurses had unsatisfactory knowledge regarding preventive and therapeutic measures of postpartum hemorrhage in the pre-test. The educational program was successful in achieving its goal of upgrading or improving their knowledge. Recommendations: The study recommends focuses on establishing plans for periodical and scheduled training courses and educational programs for nurses.
\end{abstract}

\section{Key word: Postpartum Hemorrhage, Knowledge, Maternal Mortality \& Morbidity.}

\section{Introduction}

Postpartum hemorrhage (PHH) leads to prominent causes of maternal death. The WHO estimated that the total number of maternal deaths world wide is over 3 million. Although postpartum hemorrhage remains a huge threat to both mother and health care personnel.

(WHO, 2015)

World health organization defines postpartum hemorrhage (PHH) as $500 \mathrm{ml}$ of blood loss after vaginal birth and $1000 \mathrm{ml}$ of blood loss in case of cesarean birth. The bleeding that occurs during the first 24 hours after delivery is called primary hemorrhage. When this occurs after 24 hours of birth until six week is called secondary postpartum hemorrhage. ( Knight \& Callaghan, 2016)

Postpartum hemorrhage is one of the most alarming and serious emergencies which nurse midwives may face first and there may be only a professional person when hemorrhage occurs, Her prompt and competent action will be crucial in controlling blood loss and reducing the risk of maternal morbidity or even death. Knowledgeable nurse midwife in Egypt can play an important role in management and prevention of postpartum hemorrhage. Very little is known about the actual knowledge of nurse midwives regarding prevention and management, reduction of postpartum hemorrhage risk factors (Abdel Aziem, et al., 2013).

Postpartum hemorrhage affect 1 to 5 percent of all deliveries globally. The incidence of maternal death due to postpartum hemorrhage in 2015 is about 23 cases every 100.000 deliveries in the undeveloping countries versus 12 cases death due to postpartum hemorrhage in the developed countries. (Sayl, Chou, 2014).

In Egypt postpartum hemorrhage is responsible for about (19.7\%) of maternal death and Assiut governorate has the highest percentage of maternal mortality in Egypt (81 deaths / 100.000 live birth) (kassebaum, et al., 2014).

Postpartum hemorrhage remains the leading cause of maternal morbidity and mortality in Africa and around the world. Maternal death from obstetrical hemorrhage in the Sudan contributed to $28 \%$ of the reported maternal mortality cases in 2013. (AN. Faiza, 2015)

Around $80 \%$ of woman's death occurs due to primary hemorrhage which is associated with excessive bleeding in the early 24 hours after child birth. Uterine atony is the main cause of primary hemorrhage. Other causes are retained placenta, birth canal laceration or perineum, uterine rupture, uterine inversion and coagulation disorders. (Karlson H., 2015) 
The active management of the third stage of labor involves interventions to promote expulsion of the placenta and the uterine contraction with intention of preventing or reducing blood loss. The interventions related to prevention of postpartum hemorrhage include the use of uterotonic, controlled card traction and uterine massage. Other interventions related to prevention of postpartum hemorrhage are being studied such as skin to skin contact, breast feeding and early card clamping (Ledu De Senikas, 2015)

\section{Significance of the Study}

While teaching or training the maternity nurses in ElMabara Hospital we noticed that there were is deficiency in nurses knowledge about management of postpartum hemorrhage and discussed that with my supervisor who agreed up conduct this research, there for I have done the research.

Postpartum hemorrhage is one of the most alarming and serious emergencies which nurse midwives may face first and may be only professional person present when hemorrhage occurs, her prompt and competent action will be crucial in controlling blood loss and reducing the risk of maternal morbidity or even death. Knowledgeable nurse midwife in Egypt can play important role in the prevention and management and reduction of postpartum hemorrhage. Nurses had little about the actual knowledge of management, prevention and reduction of postpartum hemorrhage risk factors (Abdel Aziem, et al., 2013).

In Egypt postpartum hemorrhage is responsible for about $19.7 \%$ of maternal death. (Kassebaum, et al., 2014) Postpartum hemorrhage remains the leading cause of maternal morbidity and mortality in Africa and around the world which is responsible for more than $25 \%$ of deaths annually world wide maternal death from obstetrical hemorrhage in Sudan contributed to $28 \%$ of the reported maternal mortality cases in 2013. (Faiza, 2015)

Postpartum hemorrhage (PPH) is an obstetrical emergency that can follow vaginal or cesarean delivery it is a major cause of maternal morbidity, and one of the top three causes of maternal mortality in both high and low per capita income countries, although the absolute risk of death is much lower in high income countries ( 1 in 100,000 versus 1 in 1000 births in low income countries ) (Mousa \& Alfirevie, 2013)

\section{Aims of the study}

The aim of Study is to

- Assess of maternity nurses knowledge about preventive and therapeutic measures of postpartum hemorrhage.
- Effect of teaching program about preventive and therapeutic measures of postpartum hemorrhage on improving maternity Nurses knowledge though implementation development.

\section{Research question}

Are the maternity nurses will get adequate knowledge about preventive and therapeutic measures of postpartum hemorrhage after teaching program implementation.

\section{Subjects \& Methods \\ Research design}

A quasi experimental (pre/post - test ) has been used in this study.

\section{Setting}

This study has been conducted in Women's Health Hospital and El-Mabara hospital which include operative and postpartum Section's in both hospitals.

Subjects

The subjects of this study includes 62 nurses who works in Women's Health Hospital \& El-Mabara Hospital.

\section{Sample}

A convenience sample was used from Women health hospital: 25 nurses (17 of them were graduate of Diploma and 3 graduated of institute of nursing and 5 Bacheloris of nursing), and El-Mabara Hospital: 37 nurses (33 of them were graduate of Diploma, 5 institute of nursing and 2 of Bachelorios of nursing).

\section{Tools of data collection}

The following tools were developed and used by the investigator for data collection.

\section{Tools I: Structure Interview Questionnaire}

This questionnaire was developed by the investigator after reviewing of literature. This tool was divided into three main parts.

Part (1): Nurse's Socio-demographic data:

Such as age, sex, education, experience years and attendance of training program before.

Part(2): this part included true or false \& multiple choice Questions to assess the nurses "Knowledge about postpartum hemorrhage".

Part (3): This part includes open question (details) to assess nurses knowledge about postpartum hemorrhage such as (definition, types, high risk group, signs, symptoms, nursing care (Before-During and After) of postpartum hemorrhage.

\section{Tool III: Teaching program Methods}

This teaching program was conducted on 3 phases.

Phase I: (preparation phase)

Ethical consideration:

-Written consent was taken from director of the place and oral consent was taken from all members of study participants. The purpose and nature of the study was explained for the directors and every 
interviewed member. Members have the right to participate or refuse participation in the study. The information that obtained is confidential and used only for the purpose of the study.

- The content validity was reviewed by expertise opinion in obstetric \& Gynecological nursing field.

- Pilot study: A pilot study was carried out before starting data collection in $10 \%$ from nurses (6 of them) included in main study to test clarity and applicability of included question and statement , content, feasibility and consistency of the tool to detect any ambiguity of this study tools. The pilot study has also served to estimate the time required to fill the form. It was included in the sample.

\section{Research question}

Do the maternity nurses have adequate knowledge about preventive and therapeutic measures of postpartum hemorrhage after teaching program implementation?

\section{Phase II: (implementation phase)}

- The process of data collection and implementation of teaching program consumed 6 months in period from January to May 2017.

- The investigators introduce herself to nurses and explained the purpose and importance of study. Hence, the approval for participation was secured from each nurse.

- Questionnaire sheet: It was handed to every participant nurse to fill in before teaching program implementation to evaluate the

Tool II: Construction of teaching program.

\begin{tabular}{|c|c|c|c|c|c|}
\hline Sessions & $\begin{array}{l}\text { Time of } \\
\text { session }\end{array}$ & Specific objectives & Content & $\begin{array}{l}\text { Method of } \\
\text { teaching }\end{array}$ & Evaluation \\
\hline Session (1) & 30 mins. & $\begin{array}{l}\text { Improve the nurses } \\
\text { knowledge about } \\
\text { general concept of } \\
\text { postpartum } \\
\text { hemorrhage }\end{array}$ & $\begin{array}{c}\text { Information about } \\
\text { definition types, causes, } \\
\text { signs, symptoms are risk } \\
\text { factors of postpartum } \\
\text { hemorrhage }\end{array}$ & $\begin{array}{c}\text { Lectures, } \\
\text { Discussion } \\
\text { booklet to easily } \\
\text { understand }\end{array}$ & $\begin{array}{c}\text { Pre and post } \\
\text { test }\end{array}$ \\
\hline Session (2) & 30 mins. & $\begin{array}{c}\text { Improve nurses } \\
\text { knowledge about } \\
\text { medical treatment of } \\
\text { post partum } \\
\text { hemorrhage }\end{array}$ & $\begin{array}{c}\text { Information about } \\
\text { medical intervention } \\
\text { such as dose, route of } \\
\text { drugs that prevent \& } \\
\text { treat post partum } \\
\text { hemorrhage such as } \\
\text { syntocinon (oxytocin) } \\
\text { misoprostol }\end{array}$ & $\begin{array}{c}\text { Lecture } \\
\text { discussion } \\
\text { booklet to easily } \\
\text { understand }\end{array}$ & $\begin{array}{c}\text { Pre and post } \\
\text { test }\end{array}$ \\
\hline Session (3) & 30 mins & $\begin{array}{l}\text { Improve the nurses } \\
\text { knowledge about } \\
\text { nursing care of post } \\
\text { partum hemorrhage }\end{array}$ & $\begin{array}{l}\text { Nursing care are include: } \\
\text { before after delivery to } \\
\text { prevent postpartum } \\
\text { hemorrhage }\end{array}$ & $\begin{array}{c}\text { Lecture } \\
\text { discussion } \\
\text { booklet to } \\
\text { understand }\end{array}$ & $\begin{array}{c}\text { Pre and post } \\
\text { test }\end{array}$ \\
\hline
\end{tabular}

Phase III: (Evaluation phase):

- The evaluation was done by the investigator to assess nurses knowledge. This was done though post assessment sheet after one month to evaluate the effect of program on gaining nurses knowledge toward postpartum hemorrhage. theoretical knowledge needs and collected by the researcher. The time for completion of questioner sheet was ranged from 15-30 minutes.

- Based on this result of this questionnaire the investigator was determined the teaching program content that was given to them.

- Theoretical content were given to nurses on the form session for 30 minutes according to their needs.

- The session time is spent in conference room in each hospital start at 8:30 Am in operative and postpartum department as previously mentioned place.

- Need explanations enquiries in addition to pressure in Arabic language, these teaching contents of pressure were based on the prassessment result.

- The program was conducted over three sessions 3 times per week to cover all information related to postpartum hemorrhage. Session were arranged to take place while nurses working during morning shift would be available, in an attempt to maximize attendance. The nurses were divided for the program not interfere with nursing daily work. The objective content, teaching methods and evaluation of the participant in session are shown in the following table. 
standard deviations, Ch-Square test were used to compare qualitative variables. Independent samples T-test was used to compare quantitate variables between groups and ANOVA test was used for more than two groups. Paired samples T-test were done to compare quantitive data between pre test and post test, P-value is considered statistically significant when $\mathrm{P}<0.05$

\section{Scoring System}

Using scoring system in the knowledge a correct response was score one grade and for uncorrected response.

-Poor $<50 \%$

-Good 50-70\%

-Excellent $>70 \%$

\section{Result}

Table (1): Distribution of demographic data in study groups.

\begin{tabular}{|c|c|c|c|c|c|}
\hline \multirow[b]{2}{*}{ Item } & \multicolumn{2}{|c|}{ G1"WHH" n=25" } & \multicolumn{2}{|c|}{ G2"MH n=37" } & \multirow{2}{*}{ P-value } \\
\hline & No. & $\%$ & No. & $\%$ & \\
\hline $\begin{array}{l}\text { Department: } \\
\text { Operative } \\
\text { Post partum unite } \\
\end{array}$ & $\begin{array}{l}11 \\
14 \\
\end{array}$ & $\begin{array}{l}44 \\
56 \\
\end{array}$ & $\begin{array}{l}22 \\
15 \\
\end{array}$ & $\begin{array}{l}59.45 \\
40.54 \\
\end{array}$ & $\mathrm{P}=0.382 \mathrm{n} . \mathrm{s}$ \\
\hline $\begin{array}{l}\text { Age "yrs." } \\
<20 \text { years } \\
\text { 20-30years } \\
>30 \text { years }\end{array}$ & $\begin{array}{c}29.45 \pm 9.67 \\
5 \\
8 \\
12 \\
\end{array}$ & $\begin{array}{l}20 \\
32 \\
48 \\
\end{array}$ & $\begin{array}{c}28.56 \pm 2.56 \\
7 \\
12 \\
18 \\
\end{array}$ & $\begin{array}{l}18.91 \\
32.43 \\
48.64 \\
\end{array}$ & $\mathrm{P}=0.473 \mathrm{n} . \mathrm{s}$ \\
\hline $\begin{array}{l}\text { Education: } \\
\text { Diploma nursing } \\
\text { Institute of nursing } \\
\text { Bacheloris nursing }\end{array}$ & $\begin{array}{c}17 \\
3 \\
5\end{array}$ & $\begin{array}{l}68.0 \\
12.0 \\
20.0 \\
\end{array}$ & $\begin{array}{c}33 \\
2 \\
2 \\
\end{array}$ & $\begin{array}{c}89.18 \\
5.4 \\
5.4 \\
\end{array}$ & $\mathrm{P}<0.03 *$ \\
\hline $\begin{array}{l}\text { 3-Work: } \\
\text { Tech. nurse } \\
\text { Nurse } \\
\text { Head Nurse }\end{array}$ & $\begin{array}{c}3 \\
17 \\
5 \\
\end{array}$ & $\begin{array}{l}12.0 \\
68.0 \\
20.0 \\
\end{array}$ & $\begin{array}{c}2 \\
33 \\
2 \\
\end{array}$ & $\begin{array}{c}5.4 \\
89.18 \\
5.40 \\
\end{array}$ & $\mathrm{P}<0.04 *$ \\
\hline $\begin{array}{l}\text { 4-Experience: } \\
\text { <2years } \\
\text { 2-5years } \\
\text { 5-10years } \\
\geq 10 \text { years }\end{array}$ & $\begin{array}{c}14.56 \pm 2.67 \\
3 \\
8 \\
6 \\
8 \\
\end{array}$ & $\begin{array}{l}12.0 \\
32.0 \\
24.0 \\
32.0 \\
\end{array}$ & $\begin{array}{c}15.59 \pm 4.44 \\
2 \\
7 \\
11 \\
17 \\
\end{array}$ & $\begin{array}{c}5.4 \\
18.91 \\
29.72 \\
45.94 \\
\end{array}$ & $\mathrm{P}=0.382 \mathrm{n} . \mathrm{s}$ \\
\hline $\begin{array}{l}\text { 5-Previous Training: } \\
\text { Yes } \\
\text { No }\end{array}$ & $\begin{array}{c}5 \\
20\end{array}$ & $\begin{array}{l}20.0 \\
76.0\end{array}$ & $\begin{array}{c}0 \\
37\end{array}$ & $\begin{array}{c}0 \\
100\end{array}$ & $\mathrm{P}<0.04 *$ \\
\hline
\end{tabular}

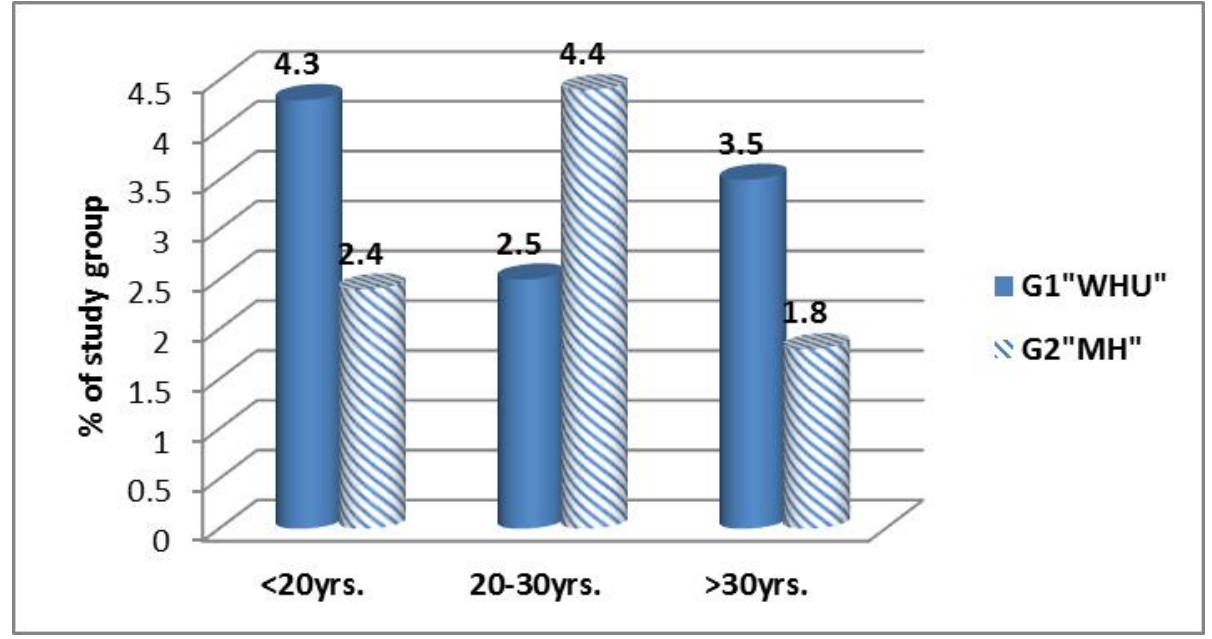

Fig (1): Distribution of age groups in different hospital. 


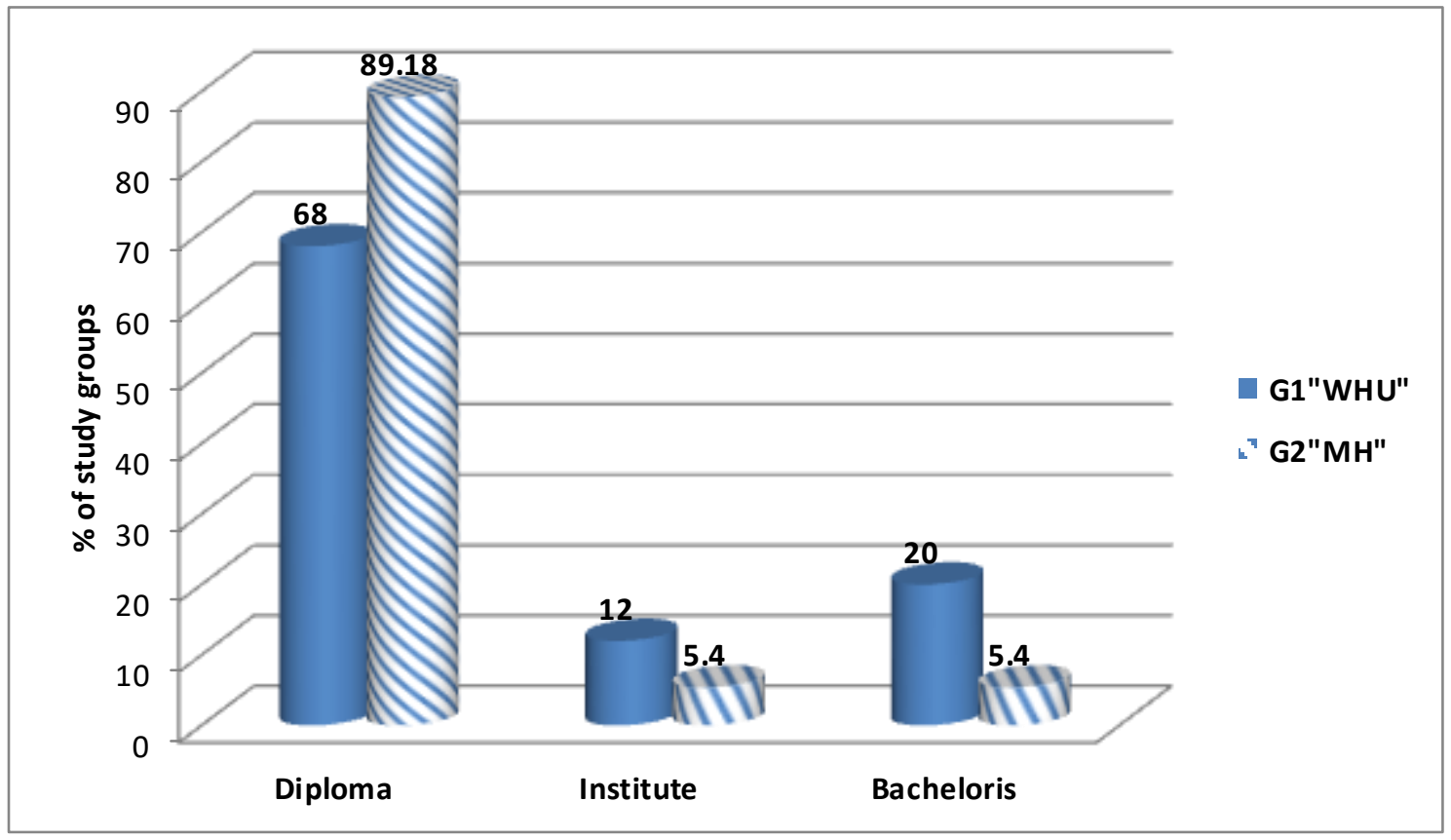

Fig (2): Distribution of education in different hospital.

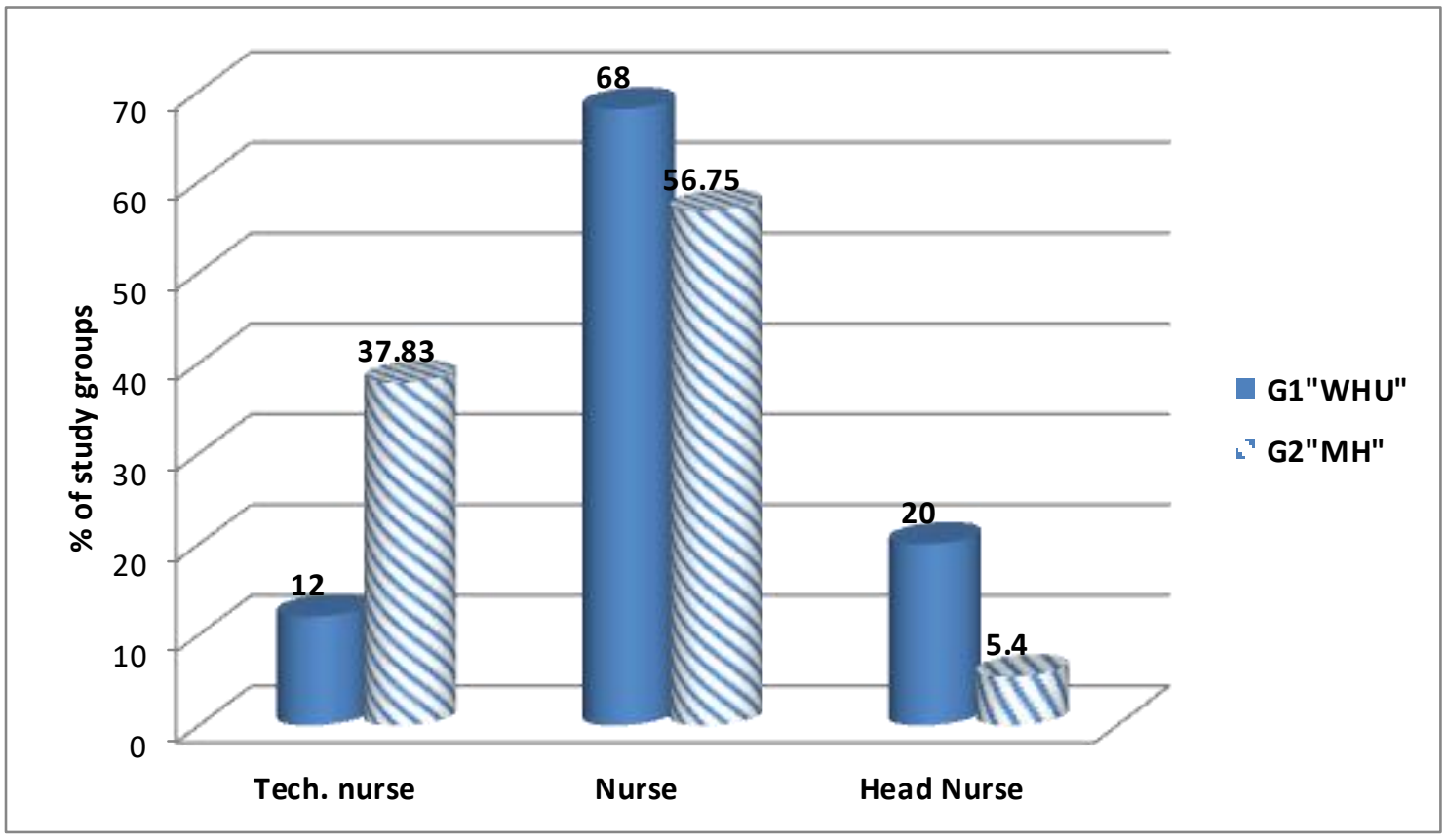

Fig (3): Distribution of work in different hospital. 
Table (2): Knowledge data in study groups "pre-program and post-program" (True and false question)

\begin{tabular}{|c|c|c|c|c|c|c|c|c|c|c|}
\hline \multirow[t]{2}{*}{ Item } & \multicolumn{2}{|c|}{$\begin{array}{l}\text { G1"WHH" } \\
\text { n=25" pre }\end{array}$} & \multicolumn{2}{|c|}{$\begin{array}{c}\text { G2"MH } \\
\text { n=37" } \\
\text { pre }\end{array}$} & \multirow[t]{2}{*}{$\begin{array}{c}\mathrm{P}- \\
\text { value }\end{array}$} & \multicolumn{2}{|c|}{$\begin{array}{c}\text { G1"WHH" } \\
\text { n=25" } \\
\text { post }\end{array}$} & \multicolumn{2}{|c|}{$\begin{array}{c}\text { G2"MH } \\
\text { "n=37" } \\
\text { post }\end{array}$} & \multirow[t]{2}{*}{ P-value } \\
\hline & No. & $\%$ & No. & $\%$ & & No. & $\%$ & No. & $\%$ & \\
\hline $\begin{array}{l}\text { 1- PPH main causes of death in } \\
\text { mother }\end{array}$ & 8 & 32.0 & 7 & 18.91 & \multirow{10}{*}{$\mathrm{P}<0.02 *$} & 13 & 52.0 & 10 & 27.02 & \multirow{10}{*}{$\mathrm{P}<0.001 * *$} \\
\hline $\begin{array}{l}\text { 2- PPH primary \&secondary start } \\
\text { after } 48 \mathrm{hrs} \text {. post delivery }\end{array}$ & 5 & 20.0 & 6 & 16.21 & & 8 & 32.0 & 6 & 16.21 & \\
\hline 3- Trauma: Injury to the birth canal & 6 & 24.0 & 5 & 13.51 & & 9 & 36.0 & 5 & 13.51 & \\
\hline $\begin{array}{l}\text { 4- Emptying the bladder at the third } \\
\text { stage of birth helps to prevent the } \\
\text { occurrence of PPH }\end{array}$ & 0 & 0 & 0 & 0 & & 0 & 0 & 3 & 8.1 & \\
\hline $\begin{array}{l}\text { 5- Women at position of trendelburg } \\
\text { during delivery prevent PPH }\end{array}$ & 2 & 8.0 & 3 & 8.10 & & 4 & 16.0 & 3 & 8.10 & \\
\hline 6- Misoprostol help to prevent PPH & 4 & 16.0 & 3 & 8.10 & & 9 & 36.0 & 3 & 8.10 & \\
\hline 7- Fundus pressure to help in delivery & 2 & 8.0 & 2 & 5.40 & & 7 & 28.0 & 2 & 5.50 & \\
\hline $\begin{array}{l}\text { 8- shivering as a side effect of } \\
\text { misoprostol }\end{array}$ & 4 & 16.0 & 2 & 5.40 & & 7 & 28.0 & 2 & 5.4 & \\
\hline $\begin{array}{l}\text { 9- Make massage after delivery of } \\
\text { placenta prevent PPH }\end{array}$ & 12 & 48.0 & 9 & 24.32 & & 16 & 64.0 & 9 & 24.32 & \\
\hline $\begin{array}{l}\text { 10- Early breast feeding prevent } \\
\text { PPH }\end{array}$ & 13 & 52.0 & 11 & 29.72 & & 15 & 60.0 & 11 & 29.72 & \\
\hline
\end{tabular}

Table (3): Knowledge data in study groups "pre\& post program" in WHU (details question ).

\begin{tabular}{|c|c|c|c|c|c|c|}
\hline \multirow[b]{2}{*}{ Item } & \multicolumn{3}{|c|}{ pre program } & \multicolumn{3}{|c|}{ post program } \\
\hline & $\begin{array}{l}\text { G1"WHH" } \\
\text { " } n=25 "\end{array}$ & $\begin{array}{l}\text { G2"MH “" } \\
\text { "n=37" }\end{array}$ & p-value & $\begin{array}{l}\text { G1"WHH" } \\
\text { " } n=25 "\end{array}$ & $\begin{array}{l}\text { G2"MH “" } \\
\text { "n=37" }\end{array}$ & p-value \\
\hline 1-Definition of PPH & $2.03 \pm 0.47$ & $1.78 \pm 0.25$ & \multirow{7}{*}{$\mathrm{P}<0.01 *$} & $3.01 \pm 0.33$ & $1.99 \pm 0.36$ & \multirow{7}{*}{$\mathrm{P}<0.02 *$} \\
\hline 2-Definition of WHO about PPH & $1.67 \pm 0.35$ & $0.25 \pm 0.02$ & & $1.89 \pm 0.47$ & $0.84 \pm 0.13$ & \\
\hline $\begin{array}{l}\text { 3-Types \& stages of PPH } \\
\text { "primary \& secondary" }\end{array}$ & $1.56 \pm 0.13$ & $0.33 \pm 0.04$ & & $1.94 \pm 0.22$ & $1.03 \pm 0.12$ & \\
\hline 4-Causes of PPH & $1.98 \pm 0.89$ & $1.23 \pm 0.64$ & & $2.02 \pm 0.99$ & $2.12 \pm 0.98$ & \\
\hline 5- Dose of Misoprostol & $2.47 \pm 0.75$ & $2.01 \pm 0.56$ & & $2.86 \pm 0.91$ & $2.43 \pm 0.77$ & \\
\hline 6-Route of Misoprostol & $0.27 \pm 0.04$ & -- & & $1.03 \pm 0.24$ & $0.99 \pm 0.14$ & \\
\hline $\begin{array}{l}\text { 7-Role of nursing care" before- } \\
\text { during-after" delivery. }\end{array}$ & $3.02 \pm 0.98$ & $2.01 \pm 0.03$ & & $3.67 \pm 0.99$ & $2.33 \pm 0.21$ & \\
\hline
\end{tabular}

Table (4): Total Knowledge data in study groups "pre-program".

\begin{tabular}{|l|c|c|c|c|c|}
\hline & G1"WHH" & n=25" & G2"MH & n=37" & \\
\hline \multicolumn{1}{|c|}{ Item } & No. & \% & No. & \% & P-value \\
\hline Total score "100" & $62.34 \pm 3.76$ & & $42.67 \pm 2.07$ & & \\
- Excellent "> 70" & 0 & 0 & 0 & 0 & \\
• Good"50-70" & 4 & 16.0 & 5 & 13.51 & $\mathrm{P}<0.02 *$ \\
- Poor "<50" & 21 & 84.0 & 32 & 86.48 & \\
\hline
\end{tabular}




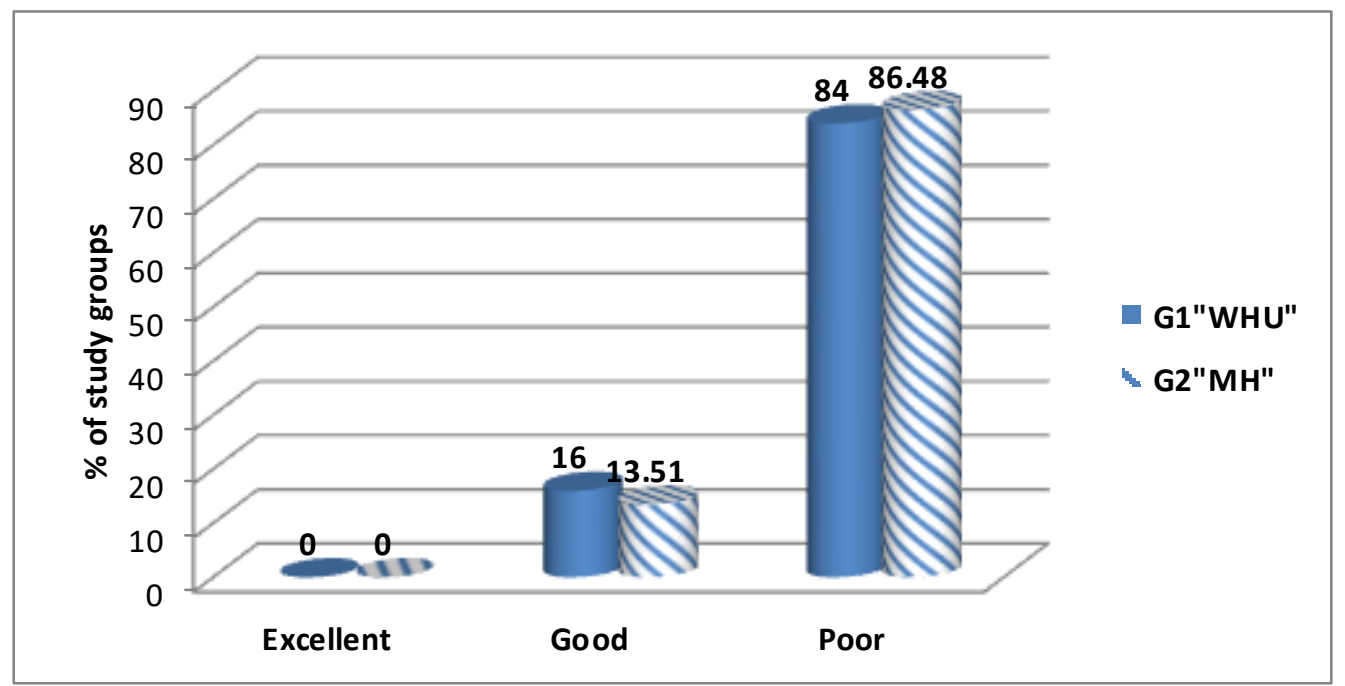

Fig (4): Total Knowledge data in study groups "pre-program"

Table (5) Total Knowledge data in study groups "post-program".

\begin{tabular}{|l|c|c|c|c|c|}
\hline \multicolumn{1}{|c|}{ Item } & \multicolumn{2}{|c|}{$\begin{array}{c}\text { G1"WHU" } \\
\text { n=25" }\end{array}$} & \multicolumn{2}{c|}{ G2"MH n=37" } & P-value \\
\hline & No. & \% & No. & \% & \\
\hline \hline Total score "102" & $77.89 \pm 6.02$ & & $47.37 \pm 3.44$ & $47.37 \pm 3.44$ & \\
• Excellent ">72" & 1 & 4 & 0 & 0 & \\
- Good"51-72" & 5 & 20 & 7 & 18.91 & P<0.000*** \\
• Poor "<51" & 19 & 76 & 30 & 81.08 & \\
\hline
\end{tabular}

WHU: Women Health Hospital MH: El-Mabara Hospital

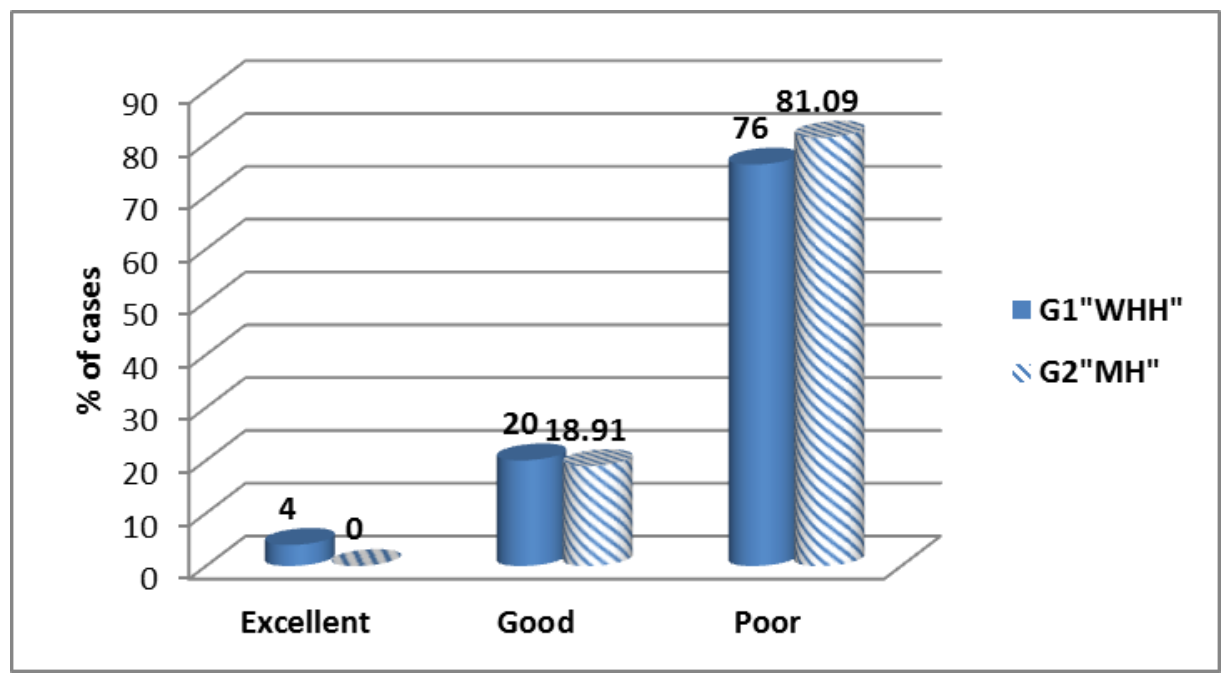

Fig (5): Total Knowledge data in study groups "post-program". 


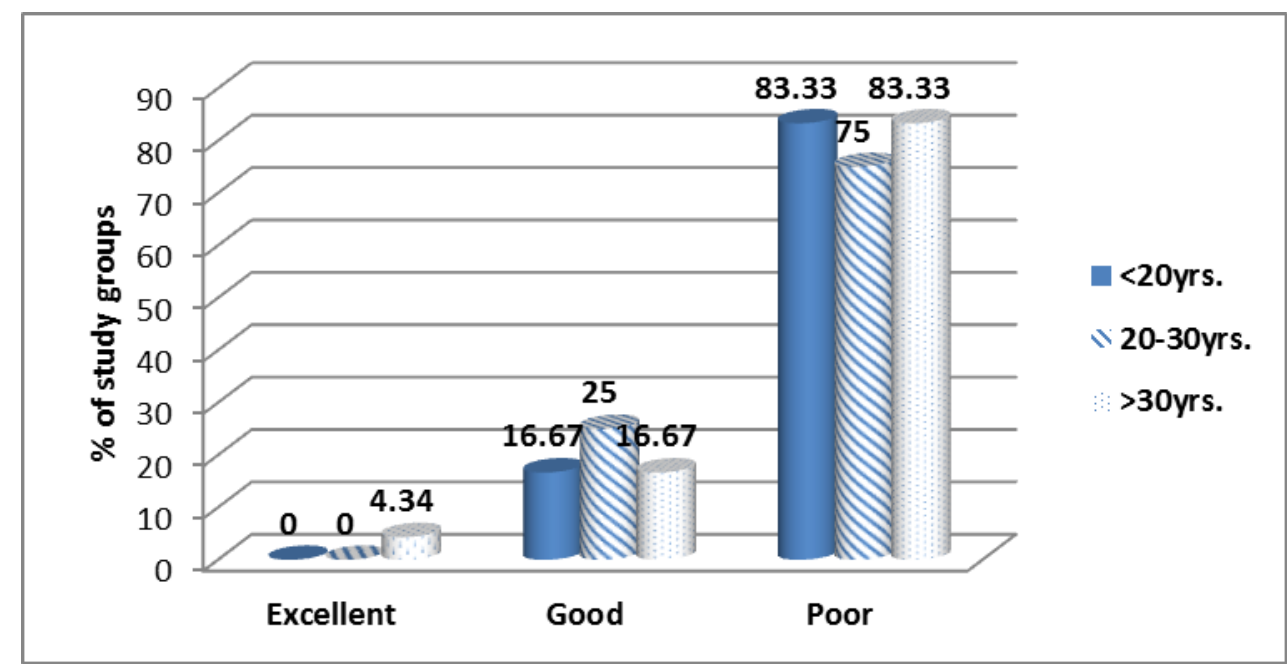

Fig (6): Relation between total knowledge of PPH \& age groups. "post -program"

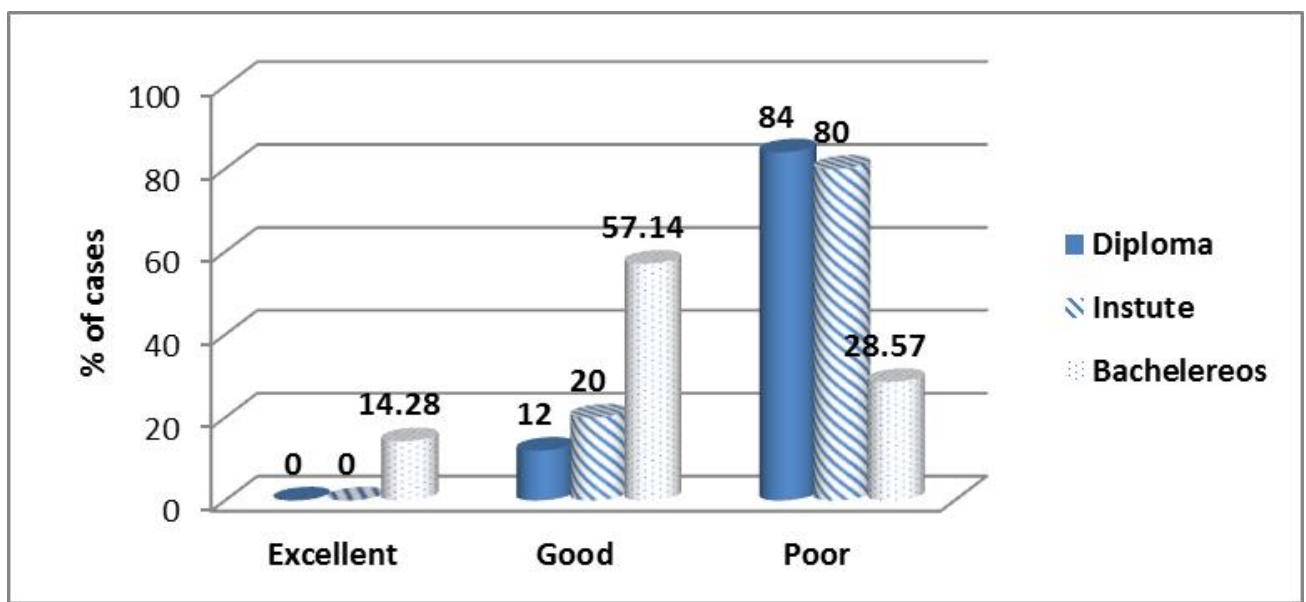

Fig (7): Relation between total knowledge of PPH \& levels of education. "Post-rogram".

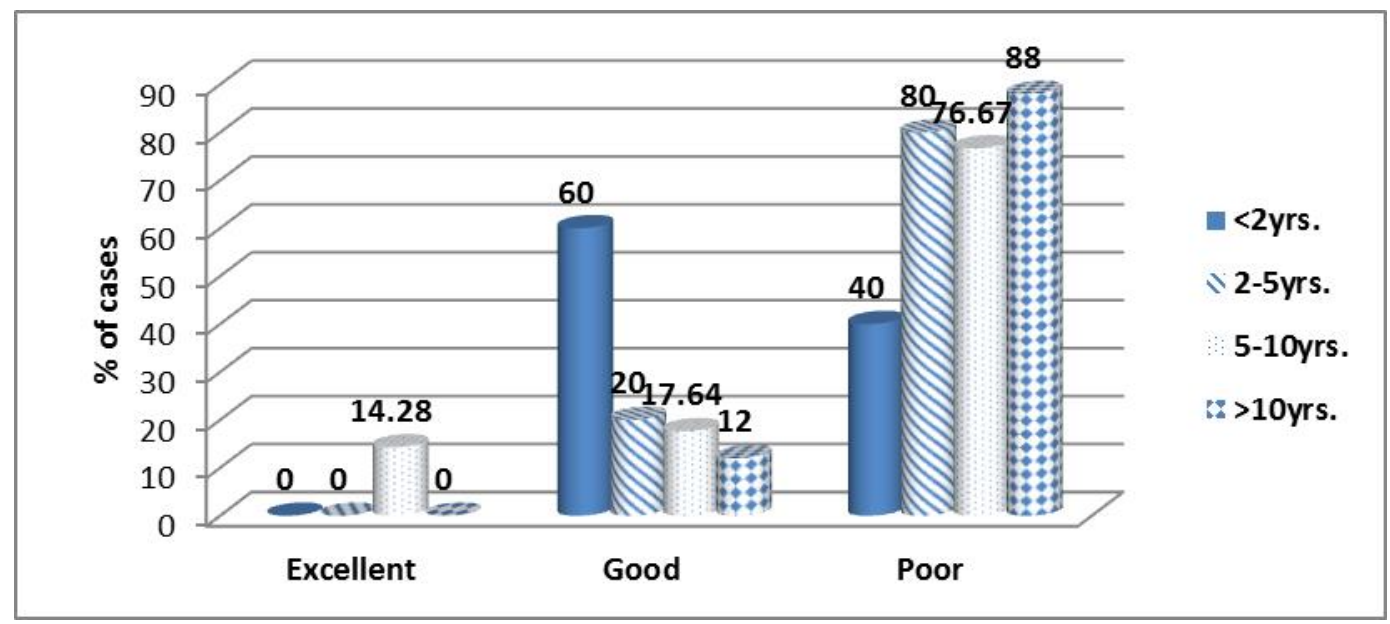

Fig (8): Relation between total knowledge of PPH \& experience" post-program"

Table (1) : Shows distribution of demographic data in study groups. There were non significance difference between no. of nurses in department, age and department $(\mathrm{P}>0.05)$, but there were significance difference $(\mathrm{P}<0.05)$ between both hospitals in each of education, level of education and work. 
Fig(1): Show that half of study group their age is 30 years in both hospital, in woman health university (12) nurses \& (18) nurses in El-mabara Hospital with no significant difference in both hospital $(\mathrm{P}=$ 0.973n.s)

Fig(2): Show more half of them were graduate of diploma in both hospital. Women health hospital: 25 nurses (17 of them were graduate of Diploma and 3 of them instituate of nursing and 5 Bacheloris of nursing). El-mabara hospital: 37 nurses (33 of them were graduate of Diploma, 5 institute of nursing and 2 Bachelorios of nursing) with significant difference in both hospital $\mathrm{P}<0.03^{*}$.

Fig(3): Show more half of them were work of nurses diploma in both hospital. Women health hospital: 25 nurses (17 of them were works of nurses and 3 of them technical of nursing and 5 Head nurses). Elmabara hospital: 37 nurses (33 of them were works of nurses, 5 technical nurses and 2 head nurses) with significant difference in both hospital $\mathrm{P}<0.04^{*}$.

Table (2): shows knowledge data in study groups "pre \& post program". There were significance difference $(\mathrm{P}<0.05)$ between hospitals in knowledge of PPH causes, types using misoprostol and early breast feeding, also there were moderate significance $(\mathrm{P}<0.001)$ about knowledge about doing after delivery of placenta prevent PPH.

About post program there were significance difference $(\mathrm{p}<0.05)$ about knowledge of PPH causes, treatment and prevention in women health Hospital .

Table (3): Shows knowledge data in study groups "pre \& post program". There was moderate significance difference about scores of knowledge of definition of PPH and definition of PPH about WHO, also there were significance difference $(\mathrm{P}<0.05)$ between types \& stage PPH \& Role of nursing care. But no significance difference between two group about using misoprostol $(\mathrm{P}>0.05)$.

About "post-program". There were moderate significance difference $(\mathrm{P}<0.001)$ post program about definition of PPH and definition of WHO about PPH. Also there were significance difference about knowledge of types \& stages of $\mathrm{PPH}$ and role of nursing $(\mathrm{P}<0.05)$. As regard there were significance difference $(\mathrm{P}<0.05)$ about role of nursing care after delivery.

Table (4): Shows total Knowledge data in study groups "pre-program". There were significance difference $(\mathrm{P}<0.05)$ between two hospitals preprogram with total score of knowledge with higher in mean value in Women health hospital than ElMabara hospital.

Table (5): Shows total Knowledge data in study groups "post-program". There were highly significance difference $(\mathrm{P}<0.000)$ between two hospitals with higher in mean value in women health unite, also there were $(4 \%)$ of cases in women health unite have excellent in knowledge vs. no cases in ElMabara hospital.

Figure (6): Shows relation between total knowledge of PPH \& age groups."post-programm". There were $(4.34 \%)$ of cases had excellent in age group more than 30years vs. no cases in other age groups. With moderate significance difference $(\mathrm{P}<0.001)$.

Figure(7): Shows relation between total knowledge of PPH \& levels of education. "Post-program". There were higher total score of knowledge in bachelereos of nursing than other level of education with highly significance difference $(\mathrm{P}<0.000)$. Also there were $(14.28 \%)$ of nurses in bachelereos of nursing in excellent knowledge vs. no nurses in other level of education.

Figure (8) Shows relation between total knowledge of PPH \& experience" post-program". There were higher in mean value of total score of knowledge in group who had experience more than 5years and more than 10years with highly significance difference $(\mathrm{P}<0.000)$.

\section{Discussion}

Postpartum hemorrhage (PPH) is the major cause of maternal mortality and morbidity. It is estimated that postpartum hemorrhage is the most common causes of maternal deaths across the globe, responsible for less than half of deaths annually. Postpartum hemorrhage is the leading cause of maternal mortality worldwide with a with minority prevalence recorded.(Lale Say, et al., 2014).

A number of factors contributes to much less favorable outcomes of PPH in developing countries which the first is a lack of experienced caregivers which might be able to successfully manage PPH if it occurred. In Addition to the same drugs used for prophylaxis against $\mathrm{PPH}$ in active management of the third stage are also the primary agents in the treatment of PPH. Lack of blood transfusion services, anesthetic services, and operating capabilities also plays a role. Finally, the previously mentioned comorbidities are more commonly observed in developing countries and combine to decrease a woman's tolerance of blood loss (Lutomski, et al., 2012).

In the United State (US) PPH has continued to be one of the most common causes of maternal death, with research supporting that more than half of those deaths could have been prevented (Berg, et al., 2010).

Nurses play an important role in early detection of high risk factors of Post-partum hemorrhage and its management. In addition, maternity nurses play an important role to ensure the safety of the mother and her baby during delivery and how to deal with them. 
The aim of this study was to assess knowledge of maternity nurses about preventive and therapeutic measures of postpartum hemorrhage in women's Health Hospital and El-Mabara Hospital and the effect of teaching program on nurses knowledge about preventive and therapeutic measures of postpartum hemorrhage pre and post teaching program implementation. In order to improve services and reduce maternal mortality and morbidity associated with Postpartum hemorrhage.

Therefore, this study was undertaken to provide nurses, as healthcare providers, with the knowledge, and skills necessary to provide care to the women with postpartum hemorrhage. The present study included more than half of nurses and it was found that half of them are aged 30 years or more it was found that majority had secondary education, and minority had technical institute and university education.

In present study there were minority of nurses who works in women health University who receive training course versus. nurses in El-mabara hospital had no training with significance difference.

In present study the majority of nurses there had education level diploma of nursing in Woman's Health University and El-Mabara Hospital respectively. These results are similar to the study of (BB Mohamed Elfrok, 2015) at Omdurman Maternity Hospital and Ribat University Hospital, and they were assessed for their knowledge towards postpartum hemorrhage in the aspect of management and prevention.

Demographic characteristic of participants have shown that, the most common age group was forty seven to fifty five yearsm followed by twenty to twenty eight years, and their education indicated that, they were mostly secondary school graduates or intermediate school graduates and Bachelor degree holders represented more than fifth of study group and Nurse midwives mostly had experience of twenty one years or more, followed by those who had one to ten years.

Nurse educational opportunities are geared toward helping nurses gain knowledge, skills, and critical thinking ability as a means of improving patient outcomes. Beal, Riley, and Lancaster (2008) stated that a healthy nurse work environment supports professional nurse development that in turn helps promote the improved outcomes. The American Nurses Association (2017) stated that professional nurse development is a nurse's ability to build on their basic education and experiences to provide quality care therefore education can influence a nurse's expertise by providing a theoretical and clinical knowledge base that can be evaluated and refined. It explained that a nurse's expertise affects their decision making when faced with an actual clinical situation. It investigated what nursing characteristics positively affected patient outcomes (Mc Hugh \& Lake, 2010 ).

(Yakusheva et al., 2014) found that overall nurses had a significant impact on patient outcomes and had an even greater effect if the nurse held a baccalaureate degree and high expertise level. These positive impacts toward patient care were shown to shorten patient length of stays and lower costs.

Regarding the nurses knowledge about the definition and the types of PPH before the training program, it was found that more than half of them did not know the correct answer. This lack of knowledge may be related to their level of education, while the correct answer increased to $80 \%$ after training program this study agree with (A.N. Faiza, 2015). In which the participants showed poor knowledge towards the definition of postpartum hemorrhage $(36.4 \%)$ before training program, but they had good about definition of postpartum hemorrhage to $(84.5 \%)$.

In the present study, it was found that there is a lack of knowledge about the identification of high risk group.

This agree with (Stocker, et al., 2014) who reported Lack of knowledge Before educational program this may be due to the fact that, nurses did not receive adequate information about postpartum hemorrhage or may be need for refreshment in-services training, regarding high risk factors during pregnancy that may lead to or predispose to PPH.

The training seemed to result in change of practice in the wards. A probable explanation is related to improved teamwork. This might have enabled staff members to work as teams during clinical emergencies, improved communication, providing a more efficient and higher quality of maternal care. A technical skill like bimanual uterine compression, which was trained on the birthing simulator (Stocker, et.al, 2014) might also have made a difference.

It takes a combination of knowledge, skills, caution, empathy and determination to perform bimanual compression as a life-saving procedure, because of the painful procedure imposed on the mother right after childbirth. The hands-on training on bimanual uterine compression made them practice this skill during the scenarios on $\mathrm{PPH}$, and might have provided the necessary competence to carry out this procedure in clinical practice (Evans, et al., 2014). In present study there were significance difference $(\mathrm{P}<0.05)$ between hospitals in knowledge of $\mathrm{PPH}$ causes, types using misoprostol and early breast feeding, also there was moderate significance $(\mathrm{P}<0.001)$ about knowledge and doing after delivery of placenta prevent PPH. About post program there were significance difference $(\mathrm{p}<0.05)$ about 
knowledge of PPH causes, treatment and prevention in women health hospital.

This study agree with ( Jos North Nigeria, 2017) In which the level of knowledge and management of post partum hemorrhage among skilled birth attendants in Primary Health Care of Jos North Nigeria. It shows that majority of Registered Nurses and Registered Midwives (RN/RM) were found to demonstrate high level of knowledge in the management of $\mathrm{PPH}$, this is in agreement with the finding of (Mutunga et al., 2015) which state that majority of midwives could diagnose PPH, suture perineatears this is also in line with (Faiza et al., 2009) findings which state that more than half of Nurse Midwives have high knowledge of PPH and management skills required for handling of $\mathrm{PPH}$, this may be due to their training which may not be the same with the CHEW and JCHEW who demonstrated less than half low and minority low knowledge respectively (Faiza et al., 2009).

About more than half of the respondent indicated that they have seen woman with PPH at the primary health care centre of Jos north. This is in accordance with the finding of (Olowokere et al., 2013) who reported that less than half of most women with $\mathrm{PPH}$ cases are referred from primary health care centre. This different may be due to intervention strategies provided in handle $\mathrm{PPH}$ in western part of Nigeria which might not have be done in Jos north primary health.

In present study there were moderate significance difference between woman's health hospital and Elmabara hospital about definition of PPH according WHO. This agrees with (Kolade et al., 2014) who reported less than half of respondents indicated that, they have management protocol on $\mathrm{PPH}$ this is in agreement with World Health Organization (WHO) guide line for management of $\mathrm{PPH}$ which recommend aloose-leaf insert of this are path ways that should be included for use as a wall chart . Every primary health care should have guideline protocol for managing PPH before referral. More than of respondent do not have management protocol for management of PPH at their clinic.

In present study there were about less than half of nurses make massage after delivery and using misoprotol help to prevent PPH. This agree with (Mutihir, et al., 2011 ) who reported that about more than half of respondent, have management PPH at various primary care centre of Jos north, among the management skills for the prevention and the control of PPH. It stated that it includes early cord clamp after 3 minute, empty of bladder during third stage of labor, placing women in trendeleburg position and use of uterotonics.
This is in agreement with World Health Organization (WHO) which outline guideline for management of $\mathrm{PPH}$ whenever as killed provider is assisting with the delivery, active management in administrative of auteronic soon after the birth of the baby, clamping of the cord following the observation of the uterine contraction at around 3 minutes and delivery of the placenta by controlled cord traction, following uterine massage (WHO, 2012).

More than half respondent, have not applied anti shock garment on client. This is in agreement with (Kolade et.al, 2014) which carries out a similar research in Western Nigeria which stated that more than half of midwives had never applied it on patient but have heard of it. The reason may be, there are no provisions for non-pneumatic anti shock garment as a first aid device that may assist to survive in case of delay transport and therefore receive definitive treatment.

In this study, there were minority of nurses know about PPH primary \& secondary start after $48 \mathrm{hrs}$ post-delivery. This agree with (Asuke, 2016) who reported that less than half of the respondents indicate that patients with PPH are referral to secondary faculties. This is in sharp contrast with (Asuke et.al, 2016) who reported only less than half of rural had good knowledge of referral; there as on may be due to years of working experience and continuous health education on the need for referral less than half of respondents aren't referral patient with PPH. There is an urgent need for training on referral system for combating PPH in primary health in resource limited settings.

The majority of Respondents indicate that there is no provision for an ambulance or transportation in cases of emergencies. This is in line with (Chinomnso et al., 2016) finding who reported that minority respondents refusing referral to higher level of care due to lack of transportation in the primary health care.

In this study, we found that nurses in WHU have higher level of knowledge about management of post partum hemorrhage than $\mathrm{MH}$ nurses We also found that there is significant relationship between the level of knowledge and professional qualification as well as significant relationship between level of knowledge and years of working experience, Thus, as the professional qualification and years of working experience increases, the level of knowledge about $\mathrm{PPH}$ increases and vice versa.

\section{Conclusion}

Based on the results of the present study, it can be concluded that nurses knowledge regarding nursing care of postpartum hemorrhage in pretest was unsatisfactory. The educational program was 
successful in achieving its goal of upgrading and improving their knowledge.

A statistical significant difference was found between the score of knowledge before and after implementing the program.

Continuous evaluation and education for nurses is needed to determine and improve any defect related to knowledge.

\section{Recommendations}

Based on the results of this study it is recommended that

1- In general more attention toward nursing educational curriculum and implement of an educational program for updating nursing staff knowledge regarding postpartum hemorrhage must be in mind/ curriculum and mass media should make public awareness regarding postpartum hemorrhage.

2- Frequent and scheduled training program for nurses. To help in improving their knowledge.

3- Encourage nurses to attend containing education in form of workshops conferences, training programs and review update nursing care related to postpartum hemorrhage.

4- Establish library with recent scientific books and magazines in an Arabic language and budget should be allowed every year for the educational activities of nurses.

5- Guide poster or pictures about nursing management of postpartum hemorrhage should be present at work place.

6- Provision of adequate resources and facilities is crucial for introduce the services for postpartum hemorrhage.

Future research proposed to monitor the long-term effect of teaching program on nurses knowledge regarding postpartum hemorrhage.

\section{References}

1- Olowokere, O., Adekeye, A., Ogunfowokan, O., Olagunju \& O., Irinoye (2013): The prevalence, management and outcome of primary post partum haemorrhage in selected health care facilities in Nigeria. Glob.

2- Abd El-Aziem A., Abd-Alla, A., El-hadi. Miskeem (2013): Causes and incidence rate of postpartum hemorrhage at kassala new hospital, Sudan, Gezira journal of health sciences, 6 (2).

3- American Association of Women's Health, Obstetric and Neonatal Nurses. (2017): call for presenters. Retrieved from : http://www.awhonn.org/?

4- Asuke S., Ibrahim M., Sabitu K., Asuke A., igbaver, Josph S., (2016): Comparison of referrals among primary health-care workers in urban and rural local government areas in north-western Nigeria. J Med Trop 2016; 18-937.

5- Balsam Balla Mohamed Elfark, (2015): Gezira university, The national Ribat university hospital \& Im durman Maternity hospital.

6- Berg, C., Callaghan, W., Syverson, C., \& Henderson, Z., (2010): (Pregnancy - related mortality in the United states.

7- Chinomnso C., Nneue, Uzo E., Ebenebe, Chukwuma B., Duru, Nonye B., Egenti, Obiageli F., Emelumadu, \& Christian C., Ibeh (2016): Availability and Continuity of Care for Maternal Health Services in the Primary Health Centres in Nnewi Nigeria.; 7: 44. Doi: 10.4103/2008-7802.177885.

8- Evans C., Johnson P., Bazant E., Bhatnagar N., Zgambo J., Khamis A., (2014): Competency-based training "Helping Mothers Survive Bleeding after Birth" for providers from central and remote facilities in three countries.

9- Faiza. A., (2015): Knowledge and practice of nurse midwives pesarding management and prevention of postpartum hemorrhage in three selected teaching hospitals - khartomm state.

10- Karlsson H., Perez San Z., Hemorrgia (2015): Post Parto, analessist san Navarra [internet - 2015 Aug 20] 32 (suppl 159-67 avaliable from : http/scielo.es/pdf /assina/v325I/abstetric.pdf.

11- Kassebaum N., Bertozzi A., Coggeshall M., (2014): Global, regional, and national levels and causes of maternal mortality.

12- Knisht M., Callaghan W., Berg C., Alexander S., Bouvier-colle M., Ford J., Joseph K., Lewis G., Liston R., Rebert C., Oats \& Walker J., (2015): Trend in postpartum hemorrhage .

13- Kolade, Oluwakemi Ajike; Dr. Tijani Wakili Adelani; Oladeji, Michael Oloyede; Dr. Ajibade, Bayo Lawal (2014): Midwives' Knowledge and Utilization of Anti-Shock Garment in Prevention of Post partum Haemorrhage. IOSR Journal of Nursing and Health Science (IOSR-JNHS), Issue 1 Ver. IV, PP 09-16 www.iosrjournals.org.

14- Lale Say, Doris Chou, Alison Gemmill, Özge Tunçalp, Ann-Beth Moller, Jane Daniels, A Metin Gülmezoglu, Marleen Temmerman, Leontine Alkema (2014): Global causes of maternal death: a WHO systematic analysis. The Lancet Global Health, Issue $6, \quad$ e 323-e333 DOI: http://dx.doi.org/10.1016/S2214-109X (14)70227-X. 
15- Leduc D., Senikas V., Lalonde A., (2015): active management of third stage : $980-93$. Available from : http:/europepme.org/ abstract/med/1994/729

16- Lutomski J., Byrne B., Devane D., Greene R., (2012): Increasing trends in atonic postpartum haemorrhage in Ireland: an 11-year populationbased cohort study. Feb. 119(3):306-14

17- McHugh, M., \& Lake, E., (2010): Understanding clinical expertise: Nurse education, experience, and the hospital context. Research in Nursing \& Health, 33(4), 276-287.

18- Mousa H., Alfirevic Z., (2013): Treatment for primary postpartum haemorrhage. Cochrane Database Syst:CD003249

19- Mutihir, J., \& Utoor, B., (2011): Post Partum Maternal Morbidity in Jos. Nigerian Journal of Clinical Practice, 38-42. Dio: 10.4103/11193077.79238.

20- Mutunga, E., (2015): Competence of Midwives in Prevention and Management of Post partum Haemorrhage at Kiambu District Hospital Labour Ward, Kiambu County.

21- Sayl, Chou D., Gemmill A., Tuncalpo, Moller A., Daniel Detal (2014): Global Causes of maternal death. Who systematic analysis, lancent global health.

22- Stocker M., Burmester M., Allen M., (2014): Optimisation of simulated team training through the application of learning theories: a debate for a conceptual framework.

23- WHO recommendations for preventing and treating PPH: evidencebase. Geneva (Switzerland): World Health Organization (WHO); (2012): 48 p. Electronic copies: Available in Portable Document Format (PDF) from the World Health Organization. Availability and Continuity of Care for Maternal Health Services in the Primary Health Centres in Nnewi, Nigeria.

24- World Health Organization. WHO (2015): guidelines the Management of postpartum hemorrhage and retained placenta [ internet ]. available from ttps/book?hI=en\&Ir=eid=val3y+lrgimc \&phis=I.

25- Yakusheva, O., Lindrooth, R., \& Weiss, M., (2014): Nurse value-added and patient outcomes in acute care. Health Services Research, 46(6), 1767-1786. 